\title{
Isolation and Identification by Morphological and Biochemical Methods of Antibiotic Producing Microorganisms from the gut of Macrotermes michaelseni in Maseno, Kenya
}

\author{
Aswani Susan Ayitso ${ }^{*}$, David Miruka Onyango \\ School of Biological and Physical Science, Maseno University. P.O BOX 333-40105 Maseno, Kenya.
}

\begin{tabular}{l}
\hline ARTICLE INFO \\
\hline Article history: \\
Received on: $21 / 11 / 2015$ \\
Revised on: $20 / 12 / 2015$ \\
Accepted on: 09/01/2016 \\
Available online: 19/02/2016 \\
\hline Key words: \\
Antibiotics, Macrotermes \\
michaeliseni, gut, \\
morphological, biochemical \\
methods.
\end{tabular}

\begin{abstract}
The major gut microflora colonizing the hind gut of higher termites, include morphologically diverse microorganisms. The objective of this study was to identify by morphological and biochemical methods of the antibiotic producing microorganisms in the gut of Macrotermes michaelseni. Macrotermes michaelseni harbor dense population of actinobacteria, which are known to produce a wide variety of secondary metabolites including many commercially important enzymes and antibiotics. In this study the Macrotermes michaelseni were collected from actively growing mound in Maseno University compound. Hind gut homogenates were serially diluted in sterile basal salt solution $\left(10^{4}, 10^{5}\right.$ and $\left.10^{6}\right)$ then pasteurized in a hot water bath at a temperature of $63{ }^{\circ} \mathrm{C}$ for 30 minutes and finally transferred onto plates containing the solid media MM7 and MM7 + glucose + Asparagine. The isolates obtained were different morphologically. Gram stain determination showed that majority of the isolates had gram negative bacteria. Indole, Citrate utilization and Triple sugar iron tests were carried out on the nine out of the seventeen isolates that showed particularly strong inhibition patterns. Biochemical tests carried out confirmed that termite gut harbour different additional indigenous microorganisms where Salmonella paratyphi, Shigella species and Shigella flexneri were identified.
\end{abstract}

\section{INTRODUCTION}

The termite gut consists of fore gut (which includes the crop and muscular gizzard), the tubular mid gut (which as in other insects is a key site for secretion of digestive enzymes and for absorption of soluble nutrients) and relatively, a voluminous hind gut (which is also a major site for digestion and for absorption of nutrients). The pheenetics diversity of the termite gut microbiota is remarkable and has been documented for both lower [1] and higher [2] termites. Although some bacteria colonize the fore gut and mid gut, bulk of intestinal microbiota is found in the hind gut, especially in the paunch, the region immediately posterior to the enteric valve. [3] reports that arthropod gut provides a suitable niche for microbial activity, but the nature of microflora and their distribution depends on the

\footnotetext{
* Corresponding Author

Aswani Susan Ayitso, Department of Biological Sciences, MasenoUniversity, P. O. Box 333-40105, Maseno, Kenya.

Email : aswanisusan@yahoo.com,Tel+254-704866275
}

physicochemical conditions like $\mathrm{pH}$, redox potential and hind guts shows that they are purely anoxic environment together with steep axial $\mathrm{pH}$ gradients in higher termites.

Among the different physiochemical conditions, $\mathrm{pH}$ and redox potential are the important factors which determine the type of microflora in the gut, while the $\mathrm{pH}$ of the fore gut and mid gut is around neutrality, whereas the paunch, colon and rectum appear to be slightly acidic. temperature of that region. [4], reports that the presence of large number of aerobic, facultative and anaerobic microflora in the However, the fore gut and mid gut of termites are aerobic with electrical potential of zero (E0') in excess of +100 mv.

The paunch and colon are anaerobic with E0' at about -230 to $270 \mathrm{mv}$, whereas the hind gut of termites is reported to show 120 to $270 \mathrm{mv}$, which proves the anaerobic conditions of the gut. Termites are good sources of wood degrading enzymes such as cellulase-free xylanases [5]. Most studies on termite gut microbial communities have focused on wood feeding termites; analogous studies of other feeding guilds, especially soil feeders are lagging behind, owing to their typically remote habitat, delicate nature and the difficulty of establishing permanent laboratory cultures $[6,7]$. 
Soil on the other hand is a highly heterogenous environment [8] that contains a high diversity of microorganisms [8]. These microorganisms influence above ground ecosystems by contributing to soil structure and fertility among other roles [9]. Soil microorganisms are a valuable source of natural products providing important antibiotics for pharmaceuticals, enzymes and bioactive compounds for industries [10]. Termites harbor a diverse community of microbes in their gut and are dependent upon these microbes for survival in many ways. The gut flora protects the termite host from invasion by foreign bacteria by providing colonization resistance Dillon and Dillon, 2004 [11, 12]. However the emergence of multidrug resistance pathogens has rekindled the need to discover new antimicrobials from remote environments. Use of bacteria from termite guts in bioremediation will provide an environmentally safe and affordable means for rapidly and effectively eliminating a variety of hydrocarbon contaminants from the environment.

\section{MATERIALS AND METHODS}

\subsection{Study area}

The study was carried out in Maseno University. Maseno is a division in Kisumu County of Western Kenya. The sampling site is located along Kisumu - Busia highway 20 kilometers northwest of Kisumu town. Maseno lies at a latitude of $0^{\circ} 00^{\prime} 16.09^{\prime \prime}$ and longitude of $34^{\circ} 36^{\prime} 08.52^{\prime \prime}$ at altitude of $1500 \mathrm{~m}$. The mean annual rainfall ranges from $600-1200 \mathrm{~mm}$ per year and the average temperature is about $21.2^{\circ} \mathrm{C}$ with $20^{\circ} \mathrm{C}$ minimum and $23^{\circ} \mathrm{C}$ maximum daily temperatures. The vegetation is grassland with scattered bushes, dominated by Spothodea combanulata, Fucas benjamina, Cupresus funebris, Toona ciliata and herbs Bidens pilosa, Leocas calostachyus. The main economic activity is subsistence farming.

\subsection{Collection of Macrotemes species and preparation of homogenates}

The soldiers and workers were collected from an actively growing mound in Maseno Siriba campus. The Macrotermes species were sampled from the mound using a hoe. The samples were put in a plastic bag with mound soil, fungus combs and transported to the Zoology laboratory for identification. The Macrotermes species were degutted in the Botany lab using fine tipped forceps as previously described [13] then cultured on MM7 media.

\subsection{Bacterial Isolation}

Using a sterilized glass rod the extracted termite whole gut was homogenized in basal salt solution using, buffer of $\mathrm{pH}$ seven $\left(10\right.$ guts $\left.\mathrm{ml}^{-1}\right)$. Then the gut homogenates were pasteurized in a hot water bath at a temperature of $63^{\circ} \mathrm{C}$ for thirty minutes [14] to allow only those isolates that produce spores to survive. According to [15], spore forming bacteria and other members of the Bacillus genus possess genes for the catabolism of diverse carbon source and antibiotic synthesis. Gut homogenates was serially diluted in sterile basal salt solutions of $10^{-4}$ per $\mathrm{ml}, 10^{-5}$ per $\mathrm{ml}$ and $10^{-6}$ per $\mathrm{ml}$. Spread plates on culture media MM7 and MM7+ glucose + Asparagine were then prepared from $0.1 \mathrm{ml}$ of dilutions $10^{-4}$ and $10^{-5}$. These homogenates were purified in nutrient agar and stocked at $4^{\circ} \mathrm{C}$.

\subsection{Microbial colony morphology}

The configuration, margin elevation and colour of the isolates colonies were observed under a light microscope as described by [16].

\subsection{Gram type determination}

Gram type determination was conducted on 48 hour old cultures of Macrotermes isolates colony according to the standard staining technique as described by $([17]$. A thin smear of pure isolates colony was made on a clean glass slide, dried in air and fixed by passing through flame of a burner. The smear was covered with crystal violet, kept for one minute. The slide was washed with water, then covered with Gram iodine and let stand for one minute. The slide was again washed with water. Decolourized with alcohol, was achieved by rocking the slide gently for twenty seconds till the violet colour came off the slide and then washed with water immediately. This later counterstained with safranin for twenty seconds. Washed with water, blot dried and then examined under the oil immersion lens of aeroscope.

\subsection{Triple sugar iron agar (TSI)}

Triple sugar iron was used for differentiation of microorganisms on the basis of dextrose, lactose and sucrose fermentation and hydrogen sulfide production. This medium was prepared as agar slope and the pure colonies of selected Macrotermes extract were inoculated by stabbing into the butt with the aid of sterilized straight wire loop and the surface of slope was inoculated by streaking over the entire surface of the slant and then incubated at $30^{\circ} \mathrm{C}$ for forty eight hours with loose caps. Gas production was determined by cracking of the medium, formation of hydrogen sulphide was determine by the blackening of the whole buffer or a streak of ring of blackening at the slant butt junction, glucose fermentation was determined by the yellowing of the butt. The fermentation of lactose or sucrose or both was determined by the yellowing of both the butt and the slant [18].

\subsection{Motility Indole Lysine (MIL)}

Motility Indole lysine is a semisolid agar used for identification of members of family Enterobacteriacea by detecting motility, indole and lysine decarboxylation or deamination. Pure colonies were inoculated on nutrient agar for eighteen hours. A sterilized straight wire loop was used to stab the centre of the MIL medium in tubes to about one-half their length. The tubes were incubated aerobically with caps loose at $35^{\circ} \mathrm{C}$ for twenty four hours. Motility was shown by the cloudiness in the medium (growth away from the stab line). For a non-motile isolate, growth was seen along cracks in the medium caused by gas 
production, but there were clear pockets of no growth. Lysine decarboxylation was observed at the lower three-quarters (anaerobic region) of the medium for change in color of the $\mathrm{pH}$ indicator; purple color showed positive reaction for lysine decarboxylation. Formation of a highly alkaline product, overneutralizing the acid produced from glucose fermentation. Yellow color showed negative reaction. Yellow color was due to the acid production from glucose fermentation. Indole production was tested by addition of one-half dropperful of Kovacs reagent to the medium, a red ring indicated production of indole from the breakdown of tryptophan. The indole test was confirmed by test organisms inoculated into nutrient agar and then incubated at $30^{\circ} \mathrm{C}$ for forty eight hours. Kovac's reagent was then added. The formation of red colouration at the top layer indicated positive and yellow colouration indicates negative.

\subsection{Simmons citrate agar (SIM)}

Simmons citrate agar is used to differentiate species of the family Enterobacteriaceae. It is selective for bacteria that have the ability to consume citrate as its sole source of carbon and ammonium as sole nitrogen source. Pure colonies of selected Macrotermes extract were inoculated on nutrient agar for eighteen hours. Then streaked using a sterilized inoculating loop only the surface of the simmons citrate agar slant with a light inoculum. The tubes were then incubated at $30^{\circ} \mathrm{C}$ for forty eight hours with loose caps.

\section{RESULTS}

\subsection{Bacterial isolates and morphological characteristics}

Thirteen bacterial isolates were isolated from the gut of Macrotermes michaelseni using MM7+ Asparagine + Glucose medium (isolate: - 1, 2, 3, 5, 7, 8, 9, 10, 12, 13, 14, 15 and 17) and four isolates using MM7 medium (isolate: - 4, 6, 11 and 16). Isolates $2,7,10,11,12,13$ and 15 were isolated from the worker, isolates 1, 3, 4, 5, 6, 16 and 17 from the normal soldier and isolates 8,9 and 14 from a large soldier. The colonies of the two isolates (1and 8) had smooth texture, white in colour, irregular and mucoid, flat elevation.

The colonies of the two isolates ( 3 and 4 ) had rough texture, white colour, irregular shape and flat elevation. The colonies of the two isolates (5 and 17) had rough texture, cream colour, irregular shape and raised elevation. The colonies of one isolate (6) had rough texture, white colour, circular in shape, and convex elevation (plate 4). The colonies of two isolates (9 and 15) had smooth texture, cream in colour, irregular shape and flat elevation

The colonies of one isolate (10) had smooth texture, white cream colour, irregular shape and raised elevation. The colonies of two isolates (11and 13) had smooth texture, cream colour, circular shape and convex elevation. The colonies of one isolate (12) had smooth texture, white colour, circular shape and convex elevation.

The colonies of one isolate (14) had a rough texture, brown colour, irregular shape and flat elevation as shown in table 1. It is essentially difficult to differentiate the species on the basis of colony morphology. In early growth stages (forty eight hours of incubation) the isolates appeared as if filamentous growth. Mature colonies were observed with a unaided eye, but microscopy provided more detailed information. Irregular, raised, opaque colonies were best observed under reflected light. The examination of flat, smooth and translucent colonies was easier when the dissecting microscope was applied.

Table 1: Characterization of bacterial isolates isolated from gut of Macrotermes michaelseni.

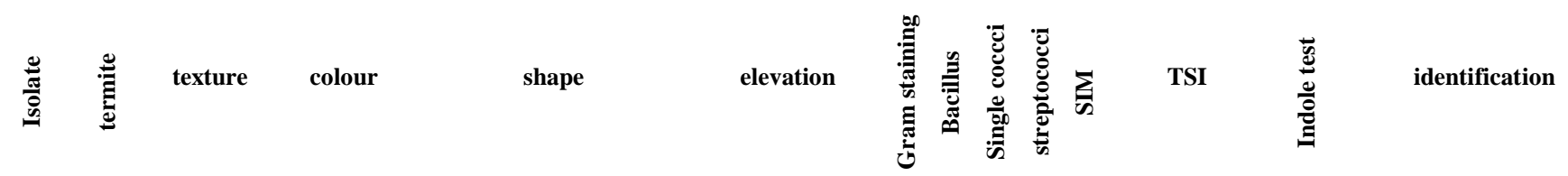

\begin{tabular}{|c|c|c|c|c|c|c|c|c|c|c|c|c|c|}
\hline 1 & NS & smooth & white & Irregular and spreading & flat & - & & + & & + & Acidic butt & - & Shigella species \\
\hline 2 & $\mathrm{~W}$ & & & & & & & & & & & & \\
\hline 3 & NS & Rough & white & irregular & flat & - & & + & & & & & \\
\hline 4 & NS & Rough & white & irregular & flat & - & + & & & & & & \\
\hline 5 & NS & Rough & cream & irregular & raised & - & + & & & - & - & - & Shigella flexneri \\
\hline 6 & NS & Rough & white & cicular & convex & - & & & + & - & - & - & Shigella flexneri \\
\hline 7 & $\mathrm{~W}$ & & & & & & & & & & & & \\
\hline 8 & LS & smooth & white & Irregular and spreading & flat & + & + & & & & & & \\
\hline 9 & LS & smooth & cream & irregular & flat & - & + & & & - & - & - & Enterobacter or Salmonella \\
\hline 10 & $\mathrm{~W}$ & smooth & cream & irregular & flat & + & & & + & + & - & + & \\
\hline 11 & $\mathrm{~W}$ & smooth & cream & circular & convex & - & + & & & & & & \\
\hline 12 & $\mathrm{~W}$ & smooth & white & circular & convex & + & & & + & & & & \\
\hline 13 & W & smooth & cream & circular & convex & - & + & & & - & - & - & Enterobacter or Salmonella \\
\hline 14 & LS & Rough & brown & irregular & Flat & - & & & + & & & & \\
\hline 15 & $\mathrm{~W}$ & smooth & cream & irregular & Flat & - & & + & & + & Gas acidic & + & Salmonella paratyphi \\
\hline 16 & NS & & & & & & & & & & & & \\
\hline 17 & NS & Rough & cream & irregular & Raised & - & & + & & - & Acidic butt & - & Shigella species \\
\hline
\end{tabular}

*NS; normal soldier, LS; large soldier, W; worker., ** - ;negative, +; positive results 


\subsection{Gram type determination:}

Gram stain determination showed that majority of the isolates had gram negative bacteria $(1,3,4,5,6,9,11,13,14,15$ and 17) while isolates 8,10 and 12 were gram positive. The contents of isolates $(4,8,9,11,13$ and 5 were found to be bacteria of the bacillus spp. While those found in isolates $1,3,15$ and 17 were found to be single cocci and the remaining four isolates $(6$, 10, 12 and 14 were found to be streptococci based on morphological appearance_as observed under the aero scope.

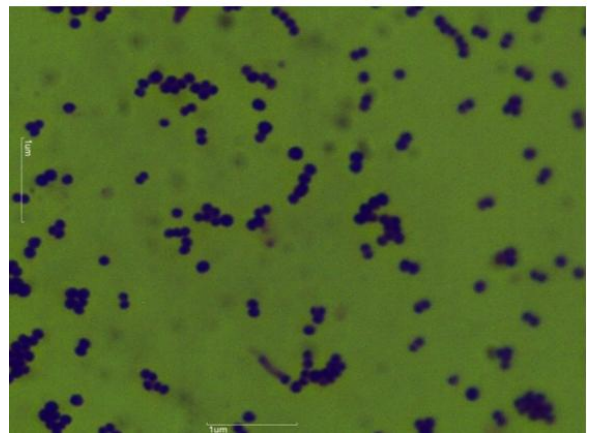

Plate 1: Bacteria cells of isolate 10 as seen under the microscope after gram staining $(\mathrm{Mg} \times 100)$

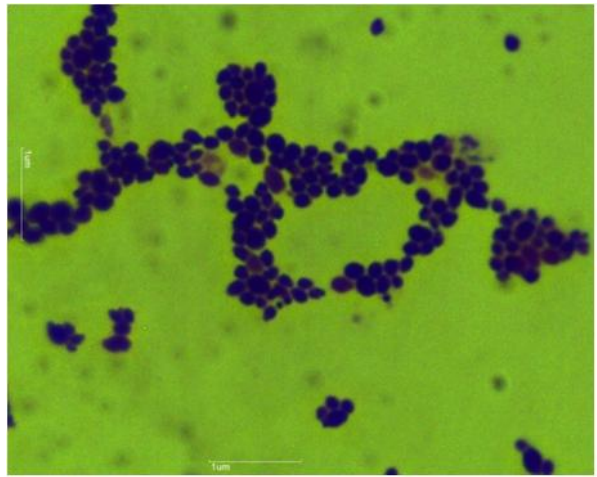

Plate 2: Bacteria cells of isolate 12 as seen under the microscope after gram staining $(\mathrm{Mg} \times 100)$

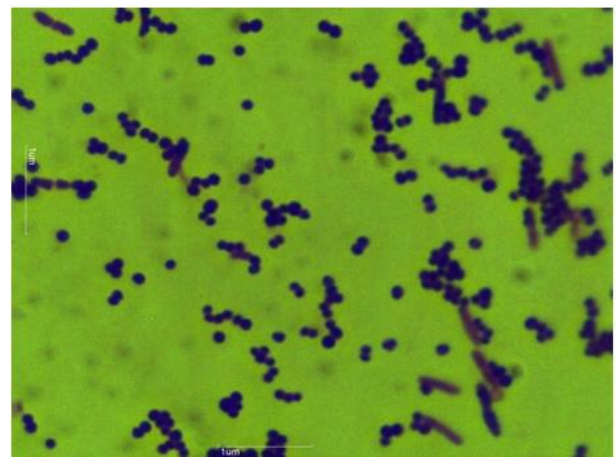

Plate 3: Bacteria cells of isolate 14 as seen under the microscope after gram staining $(\mathrm{Mg} \times 100)$

\subsection{Characterization of the most promising isolates}

However, morphology in itself was not adequate to differentiate many actinomycete genera. It had to be complemented with conventional microbiological biochemical characteristics.

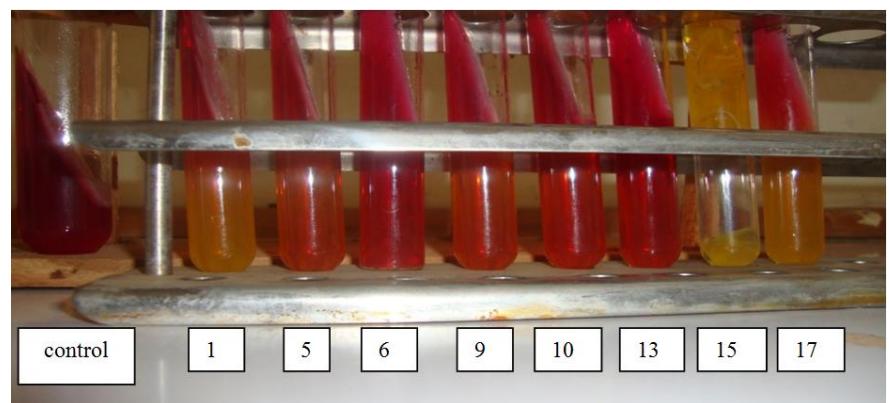

Plate 4: Triple sugar iron (TSI) slants showing negative biochemical tests in tubes 5, 6, 9, 10 and 13 . Tubes 1,15 and 17 have acidic butt, tube 15 gas is produced.

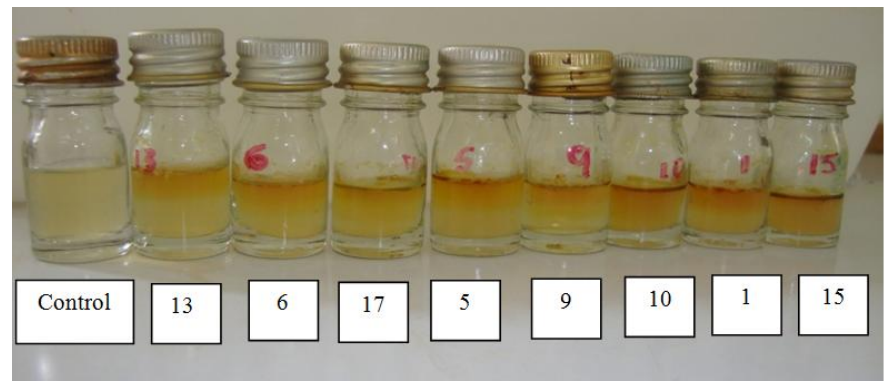

Plate 5: Indole test: nutrient agar after addition of Kovac's reagent. Tube 15 and 10 shows a positive test while tubes $13,6,17,5,9$ and 1 show negative tests.

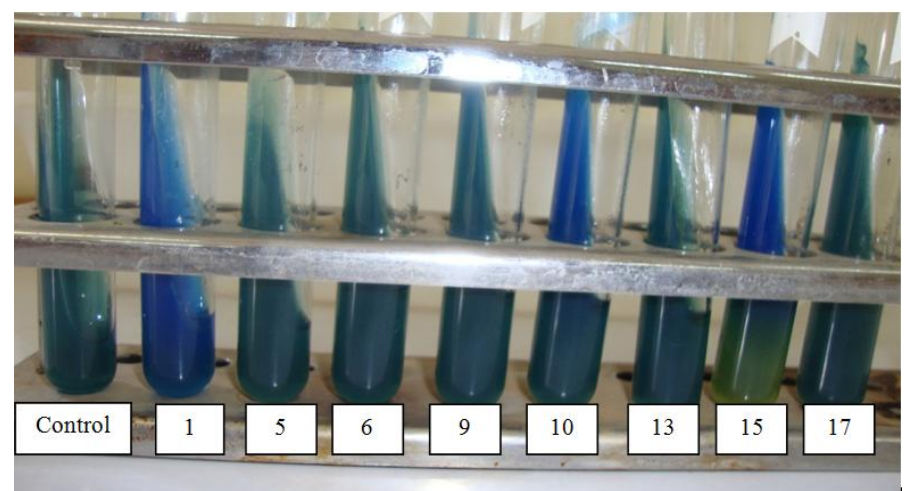

Plate 6: Citrate utilization test on Simmon's citrate agar slant. Tubes 1, 10 and 15 present positive test for citrate utilization, while tubes $5,6,9,13$ and 17 show a negative biochemical test.

\section{DISCUSSION}

\subsection{Colony morphology of isolates}

The isolates were characterized using morphological characteristics (Table 1). The bacterial isolate grew slowly on nutrient agar, visible growth was observed after two days. Growth of fungi on Potato Dextrose Agar took five days. The isolates grew at the optimum temperature of $30^{\circ} \mathrm{C}$. The microbial world is characterized by an incredible metabolic and physiological versatility that permits microorganisms to inhabit hostile ecological niches and to exploit, as carbon and energy sources, 
compounds unpalatable for higher organisms [19]. Isolates in this study displayed the typical morphological characteristics of members of the genus Enterobacter. Accurate morphological characterization of actinomycetes is dependent upon the use of a culture medium which supports good sporulation [16]. The isolates that we collected showed morphological similarities to those of Streptomyces.

\subsection{Gram staining}

The experimental results showed that most of the cells of homogenates had ability to retain the primary stain (gram-negative organisms). A few of the cells of isolates (8, 10 and 12) retained violet stain even after treatment with decolorizing agent (grampositive organisms). But a study carried out in Juja and Kakamega forest the study showed majority of isolates were gram positive bacteria and few gram negative [20]. The difference could be attributed to microorganisms being endemic to certain geographic regions hence difference in micro-ecological zones having various characteristics in Kenya is expected to harbor unique microbes as a result of different soil composition, type of food, amount of rainfall received and economic activities carried out in the area [21].

Gram stain smears showed fragmenting filaments that were branching, irregularly curved and unevenly stained, this is highly suggestive of Actinomycetes. On the other hand, fermentative Actinomycetes often appear as rods or even coccoid forms resembling Corynebacteria, Proionibacteria or Streptococci [22]. Most bacteria isolates contained in isolates obtained in this study were cocci with few rods.

Bacillus were the most frequently observed in both species of termites (workers and soldiers) based on frequency observed by gram staining technique. Cocci were missing in the larger species of termites (Larger soldiers), Streptococci were predominantly observed in workers. These results shows that the workers contained all forms of microorganisms while the larger soldiers lack cocci in their gut. This is attributed by different roles they play in their colonies. The workers who are mound builders, collect food and digest then feed the soldiers and queens, soldiers provide security in the mound and the resting queen.

These different roles they play may make them harbor different microbes so as to aid their roles in the colony. These results are consistent with the research carried out by [23]. They reported that yeasts were isolated only in the workers of $\mathrm{M}$. subhyalinus,_no Enterococcus or mould was observed. Bacteria isolated from two species of termites show that the genus Lactobacillus and Pediococcus were the most frequent in both species of termite. Pediococcus was lower in little soldier of $M$. subhyalinus. acid bacteria isolated from two species of termites show that the genus Lactobacillus is the most predominant in both M. subhyalinus and M. bellicosus. Genus Candida and genus Cryptococcus isolated only in the intestinal tract of $M$. subhyalinus worker. However, presence in the intestinal tract of anaerobic strict, anaerobic facultative and aerobic microorganisms had been demonstrated.

Another study carried out by [24] also revealed the presence of facultative anaerobic, aerobic and micro aerobic bacteria in the gut of the termite Zootermopsis angusticollis. They isolated Microbacterium sp., Kocuria varians, Bacillus cereus, Bacillus anthracis, Brevibacillus brevis and Paenibacillus sp. [25] have also shown the presence of anaerobic, heterofermentative, non-sporulating microorganisms, Gram-positive in the gut of termites Captotermes formosanus.

\subsection{Sugar fermentation}

Sugar fermentation patterns of Macrotermes isolates on tryptic sugar iron (TSI) agar showed that in isolates 6 and 13 there was deamination of aminoacids as shown by aerobic alkaline reaction on the slant. Isolates 5, 9 and 10 showed glucose fermentation as minor acidic reaction was observed in the butt, this is in consistence with the findings by [26]. Lactose and sucrose fermentation was observed in isolates 1,15 and 17 as shown by the major acidic reaction in the butt. Isolate 15 produced a gas as evidenced by cracks in the medium. Uninoculated control tube showed an orange (neutral) reaction throughout. The isolates were able to utilize wide range of carbohydrate substrates supported by findings of $([27]$.

This characteristic was shared by nearly all members of the family Enterobacteriaceae [28], and has been consistent with their wide distribution in most environmental compartments. Isolate 15 was identified as Salmonella paratyphi and isolate 1 and 17 as Shigella species (Appendix 1)

\subsection{Indole test}

Indole test of eight isolates on Indole Lysine and nutrient agar showed that there was deamination of amino acid by isolate 1 as aerobic alkaline reaction was observed, deamination of lysine by isolate 9 as dark red. Indole lysine medium was formed, decarboxylation of lysine by isolate 1 as anaerobic alkaline reaction observed in the Indole Lysine Medium, glucose fermentation by isolates 5, 6, 10, 13 and 17 as acidic reaction in the Indole Lysine Medium was observed. Motility was observed in isolates 1, 9 and 13 in nutrient agar and Indole Lysine Media. Isolates 5 and 6 were identified as Shigella flexneri (Appendix 2).

\subsection{Citrate utilization test}

Citrate utilization test on Simmon's citrate agar slant showed that isolates 5, 6, 9, 13 and 17 did not utilize citrate thus the Ssimmon's citrate agar remained green in colour. Isolates 1, 10 and 15 utilized citrate in the simmon's citrate agar thus blue slant on the medium was observed. Isolates 9 and 13 were identified as Enterobacter species or Salmonella species belonging to the family of Enterobacteriacea (appendix 3). 
Appendix 1: Triple Sugar Iron Agar (TSI Agar) for the identification of Enterobacteriaceae

\begin{tabular}{|c|c|c|c|}
\hline $\begin{array}{r}\text { Organism } \\
\end{array}$ & Butt & Slant surface & $\mathbf{H}_{2} \mathrm{~S}$ \\
\hline Enterobacter aerogenes & $\mathrm{AG}$ & $\mathrm{A}$ & - \\
\hline Enterobacter cloacae & $\mathrm{AG}$ & A & - \\
\hline Proteus vulgaris & $\mathrm{AG}$ & $\mathrm{A}$ & + \\
\hline Proteus mirabilis & $\mathrm{AG}(\mathrm{A} * *)$ & $\mathrm{NC}$ or ALK & + \\
\hline Morganella morganii & $\mathrm{AG}$ & $\mathrm{A}$ & - \\
\hline Providencia rettgeri & $\mathrm{A}(\mathrm{ALK})$ & NC or ALK & - \\
\hline Shigella dysenteriae & A & NC or ALK & - \\
\hline Shigella sonnei & A & NC or ALK & - \\
\hline Shigella schmitzii & A & $\mathrm{NC}$ or ALK & - \\
\hline Shigella boydii & A & $\mathrm{NC}$ or ALK & - \\
\hline Shigella flexneri & A & $\mathrm{NC}$ or ALK & - \\
\hline Dispar & A & $\mathrm{A}$ & - \\
\hline Salmonella typhi & A & NC or ALK & + \\
\hline Salmonella typhosa & A & NC or ALK & + \\
\hline Salmonella entericia & $\mathrm{AG}$ & NC or ALK & + \\
\hline Salmonella pullorum & $\mathrm{AG}$ & NC or ALK & + \\
\hline Salmonella gallinarum & A & NC or ALK & + \\
\hline Salmonella paratyphi A & $\mathrm{AG}$ & NC or ALK & - \\
\hline Salmonella paratyphi $B$ & $\mathrm{AG}$ & NC or ALK & + \\
\hline Salmonella enteritidis & AG & NC or ALK & + \\
\hline Salmonella typhimurium & $\mathrm{AG}$ & NC or ALK & + \\
\hline Escherichia coli & $\mathrm{AG}$ & A & - \\
\hline Citrobacter freundii & $\mathrm{AG}$ & A & + \\
\hline Klebsiella pneumoniae & $\mathrm{A}$ or $\mathrm{AG}$ & NC or ALK & - \\
\hline Pseudomonas aeruginosa & ALK & NC or ALK & - \\
\hline Alkaligenes faecalis & ALK & NC or ALK & - \\
\hline
\end{tabular}

$\mathrm{AG}=$ acid (yellow) and gas formation

$\mathrm{A}=$ acid (yellow)

$\mathrm{NC}=$ no change

$\mathrm{ALK}=$ alkaline $(\mathrm{red})$

$+=$ hydrogen sulphide (black)

- = no hydrogen sulphide (no black)

Source: Sigma- Aldrich

Appendix 2: Motility indole lysine medium for the identification of Enterobacteriaceae.

\begin{tabular}{|c|c|c|c|c|c|}
\hline Organism & ATCC & $\begin{array}{c}\text { Lysine } \\
\text { Decarboxylase }\end{array}$ & Motility & $\begin{array}{c}\text { Lysine } \\
\text { Deaminase }\end{array}$ & Indole Production \\
\hline Escherichia coli & 25922 & + & + & - & + \\
\hline Providencia alcalifaciens & 9886 & - & + & + & - \\
\hline Salmonella enterica subsp. Enterica serotype Enteritidis & 13076 & + & + & - & - \\
\hline Shigella flexneri & 12022 & - & - & - & - \\
\hline
\end{tabular}

Source: Difco ${ }^{\mathrm{TM}}$ and BBL ${ }^{\mathrm{TM}}$ manual, $2^{\text {nd }}$ edition.

Appendix 3: Simmon's citrate utilization medium for the identification of Enterobacteriaceae.

$\begin{array}{ccc}\text { Microoganisms } & \text { growth } & \text { Medium colour } \\ \text { Enterobacter aerogenes ATCC 13048 } & \text { bood } & \text { blue } \\ \text { Escherichia coli ATCC 25922 } & \text { green } \\ \text { Salmonella enteritidis ATCC 13076 } & \text { good } & \text { blue } \\ \text { Shigella dysentriae ATCC 13313 } & \text { inhibited } & \text { Good } \\ \text { Salmonella typhimurium ATCC 14028 } & \text { good } & \text { blue } \\ \text { Salmonella typhi ATCC 19430 } & \text { inhibited } & \text { green } \\ \text { Yersinia enterocolitica ATCC 27729 } & \end{array}$

Source: Laboratory of Conda, South Africa.

\section{CONCLUSION}

Termite gut harbors a large population of diverse microorganisms, which includes cocci, rods, streptococci and filamentous bacteria. Most of the isolates from the gut of Macrotermes michaelseni are gram negative. Biochemical test of the eight isolates detected Salmonella paratyphi, and Shigella flexneri present in the gut of Macrotermes michaelseni.

\section{ACKNOWLEDGEMENT}

The researchers are grateful to the Maseno University for allowing them to collect the Macrotermes michaeliseni from Siriba cumpus compound as well as isolation and identification by morphological and biochemical methods of antibiotic producing microorganisms from the gut of Macrotermes michaelseni in the University Botany laboratory. 


\section{REFERENCES}

1. Brian MV. Production Ecology of Ants and Termites, New York Cambridge University Press; 1978.

2. Eutick ML, Brien RW, Slaytor M. Bacteria from the gut of Australian termites, Applied Environtal Microbiology. 1978; 35: 823-828.

3. Bignell DE, Slaytor M, Veivers PC, Mühlemann R, Leuthold RH. Functions of symbiotic fungus gardens in higher termites of the genus Macrotermes evidence against the acquired enzyme hypothesis. Acta Microbiol. Immunology Hung. 1994;41:391-401.

4. Brune AD. Emerson and Breznak J.A. The termite gut microflora as an oxygen sink: Microelectrode determination of oxygen and $\mathrm{pH}$ gradients in guts of lower and higher termites, Applied Environmental Microbiology. 1995; 61: 2681-2687.

5. Matoub M, Rouland C. Purification and properties of the xylanases from the termite Macrotermes bellicosus and its symbiotic fungus Termitomyces sp. Comparative Biochemical Physiology. 1995; 112:629- 35.

6. Bignell DE, Oskarsson H, Anderson JM. Specialization of the hindgut wall for the attachment of symbiotic microorganisms, in a termite Procubetermes aburiensis (Isoptera: Termitidae. Termitinae). Zoomorphology. 1980; 96: 103-112.

7. Rouland C., Brauman A., Labat M. and Lepage M. Nutritional factors affecting methane emission; 1993.

8. Rolf $\mathrm{D}$. The soil metagenome as a rich resource for the discovery of natural products. Current Opinion in Biotechnology. 2004; 15: 199204.

9. O'Donnnell AG, Seasman M, Macne AN, Davies T. Plants and fertilizers as drivers of change in Microbial Community Structure and Function in soil. Plant soil. 2001; 232:135-145.

10. Strohl WR. The Role of natural products in modern drug discovery. Drug DiscoveryToday. 2000; 5: 39-41.

11. Veivers PC, O'Brien RW, Slaytor M. Role of bacteria in maintaining the redox potential in the hindgut of termites and preventing the entry of foreign bacteria. Journal of Insect Physiology. 1982; 28:947-951.

12. Dillon RJ, Dillon VM. The gut bacteria of insects: nonpathogenic interactions. Annu Rev Entomology. 2004; 49:71-92.

13. Schmitt-Wagner D, Friedrich MW, Wagner B. and Brune A. Phylogenetic diversity, abundance, and axial distribution of bacteria in the intestinal tract of two soil-feeding termites (Cubitermes spp.). Applied Environmental Microbiology. 2003; 69: 6007-601.

14. Mincer TJ, Jensen PR, Kauffman CA, Fanical W. Widespread and persistent populations of a major new marine Actinomycete taxon in ocean sediments. Applied and Environmental Microbiology. 2002; 68: 5005-501.

15. Prescott ML, Harley PJ, Klein AD. Microbiology 7th edition. Publishing Group. 2008; 42-51, 232-233, 762-764.

16. Shirling EB, Gottlieb. Methods of characterization of Streptomyces species. Introduction Journal Bacteriology. 1966;61: 313-340.

17. Hucker GJ, Conn HJ. Method of Gram staining. N Y State Agric Exp Stn Tech Bull. 1987; 93:3-37.
18. Manga BS, Oyeleke SB. Essentials of Laboratory Practical's in Microbiology (1 edition). Tobes Publishers. 2008;56-76.

19. Tariq S, Benedict CO, Muhamma A, William T. Enrichment and isolation of endosulphan degrading microorganisms. Journal of environmental quality. 2003; 32: 47-54.

20. Ntabo R, Boga $\mathrm{H}$, Muigai A, Mwirichia R. Isolation and characterization of bacteria isolates from soil feeding termites and soil from juja and kakamega forest in Kenya; 2007.

21. Torsvik V, Daa FL, Sandaa RA, Orneas L. Microbial diversity and function in soil: From genes to Ecosystems. Current Opinion in Microbiology. 2002; 5: 240-245.

22. Collins MD, Cummins CS. Genus Corynebacterium Lehmann and Neumann 1896, 350AL. In Bergey's Manual of Systematic Bacteriology. 1986; 2: 1266-1276.

23. Kuhnigk T, Branke J, Krekeler D, Cypionka H, König H. A feasible role of sulfate-reducing bacteria in the termite gut. Systematic and Applied Microbiology. 1996; 19:139-149.

24. Wenzel MI, Schonig M, Berchtold P, Kampfer H, Konig G. Aerobic and facultatively anaerobic cellulolytic bacteria from the gut of the termite Zootermopsis angusticollis Zootermopsis angusticollis. Journal of Applied Microbiology. 2002; 92:32-40.

25. Higashiguchi DT, Hussenede C, Grace JK, Berestecky JM. Pilibacter termitis gen. nov., Sp. nov., a lactic acid bacterium from the hindgut of the Formosan subterranean termite (Captotermes formosanus) International Journal of Systematic and Evolutionary Microbilogy. 2006; 56, 15-20

26. Boga HI, Ludwig RW, Brune A. Sporotaela propionica genera novel species. Hydrogen oxidizing, Oxygen reducing, propiogenic firmicutes from the intestinal tract of a soil feeding termite. Archives of Microbiology. 2007; 187 (1): 15-27.

27. Hellen AO, Hamadi IB, Nancy B, Muniru T, Darius OA. Isolation, characterization and identification of Diazinon degrading bacteria from the soil and gut of macrotermes. Journal of Biodiversity and Environmental Sciences. 2013;3: 70-79.

28. Holt GJ, Kreig RN, Sneath AH, Staley T, Williams TS. Bergey's manual of determinative bacteriology (9th Edition) William and Wilkins. Baltimore; 1994.

\section{How to cite this article:}

Ayitso AS and Onyango DM. Isolation And Identification by Morphological and Biochemical Methods Of Antibiotic Producing Microorganisms from the gut of Macrotermes Michaelseni in Maseno, Kenya. J App Biol Biotech. 2016; 4 (01): 027-033. DOI: 10.7324/JABB.2016.40105 